可視化情報 Vol.23 Suppl. No. 1（2００３～年 7 月）

C 108

高速度カメラによる角度を付けた二球の衝突挙動解析

須藤 路久 ${ }^{\circ}$ (OFFICE BiTS), 二宮 尚(宇都宮大学), 寺島 祥夫(宇都宮大学)

\title{
Collision Analysis of Two Billiard Balls by High-Speed Camera
}

\author{
Michihisa SUDO, Nao NINOMIYA and Yoshio TERASHIMA
}

\begin{abstract}
Trajectories of the billiard balls have long been assumed to behave as the collision of mass points. As a matter of fact, the beginners can enjoy the games with this simple approximation. On the contrary, the professional players know the differences from the theory by their plentiful experiences and adjust them by intuitions. For example, the target ball does not go in the direction which is perpendicular to the surface of contact. This difference from the theory is well known as "throw". In order to investigate the mechanisms of the differences from the theory and to quantify them under various conditions, the authors of this study have visualized the motions of the balls by the high-speed camera and have investigated the trajectories of the balls quantitatively by using the digital image processing techniques. As a result, the maximum "throw" is found to occur at the contact angle of 30 degree.
\end{abstract}

Keywords: High-speed camera, Digital image processing, Billiard, Collision analysis

\section{1. 緒 論}

近年,様々なスポーツに対して科学のメスが入れられ， 道具の性能が飛踓的に進歩すると共に，技術にも大きな 進歩がもたらされる様になってきた．実際にスポーツを 科学する際に, 最も一般的に用いられる手法が可視化と 画像解析である，選手や道具の動きの詳細を撮影し，そ の画像を定性的もしくは定量的に解析することによって， 最適な条件を抽出することが可能となる.

次期オリンピックから公認競技として取り入れられる ことになった撞球（ビリヤード）は，自然界の偶発的な 影響をあまり受けにくく，論理的な予測が立て易い競技 の一つであるが, 未だかつて科学的なアプローチは殆ど 行われていないというのが現状である. 高速な現象の観 察に大きな効果を持つ高速度カメラを用いた奏験も, 唯 一Shamos \& Jewett 1)による実験が行われただけであ る.この実験は, 撞球における様々な現象の詳細を捉え たものであるが, 定性的な観察しか行われておらず, し かも残念なことにその成果は一般には公表されていない， そこで,筆者らは独自に高速度カメラによる害験を行い, キューが手球を撞いた瞬間 2)3）や，的球の軌跡が論理的 な予測方向とは微妙に異なること 3)4)などを示した。

撞球の基本的な理論は，平面上で回転を伴う球の衝乫 運動を質点の衝突運動と近似して解析される.しかし，
実際には，球の速度，球の回転，床面の摩撩，球同志の 摩摖，球の素材の弾性など，種々の影響により，非常に 複雑な挙動を示す．更には，キューやクッションなどと の相互作用も含めると，とても質点の運動で近似出来る ものではない．この競技における技術の進歩や道具の性 能の向上を計るためには, 種々の複雑な要因の中から, 基本的な影響因子を特定分離し，更にその各々の因子の 影響を定量的に評価する必要がある.

\section{2. 目的}

本研究では，平面上を運動する球の衝突挙動の詳細を 高速度力メラを用いて撮影し，得られた可視化画像にデ ジタル画像処理を施すことにより，平面内での球の運動 の詳細を定量的に明らかにすることを目的とする.

平面上で回転を伴いつつ並進運動する球の衝突挙動は 非常に複雑であり，その運動メカニズムの全容を明らか にするのは困難に近い.これに対して筆者ら ${ }^{4)}$ は，画像 処理によって球の座標や速度を精度良く計測する手法を 確立し，球の反発係数や衝突前後のエネルギー及び運動 量の保存を示した. また，的球の軌跡が論理的な予測方 向とわずかに異なる「スロー」と呼ばれる現象を初めて 定量的に示すことに成功した，本研究では，種々の条件 下において，このスローがどの様に変化するか，その詳 細を明らかにすることを目的とする. 


\section{3. 実験方法及び実験装置}

実験に用いる球と台は, 実際に撞球で用いられるもの を使用した. 球は Brunswick 社製で, 材質はフェノール 樹脂, 質量は平均 $168.62 \mathrm{~g}$, 直径は平均 $57.172 \mathrm{~mm}$ で あった. 台は(株)アダム製で, 表面は石盤に羊毛のラシ ヤを張った物である. 設置に際しては台の水平に十分注 意を払った. 撮影に際しては, 真上から撮影するために, アングルによりカメラを台の中央上方約 $1.5 \mathrm{~m}$ の位置に 固定した. 照明には $150 \mathrm{~W}$ のメタルハライドライトを二 灯用い, 球の影が出来ない様にした.

Fig. 1 は, 本研究で用いた撮影装置の概略図で, 高速 度カメラには, (株)フォトロン製 FASTCAM ultima-2 を 用い, 球がフォトインタラプタを横切る際の信号を外部 トリガとして, 撮影の開始や終了の同期を行った. 高速 度カメラに記録された画像は, (株)SONY 製デジタルビ デオカメラ DCR-TVR900 に逐次 NTSC 信号で記録した. このビデオは, 任意のコマの静止画をメディアにデジタ ル記憶出来る様になっており, 実験終了後, 順次取り出 して, 各コマ毎にデジタル画像処理を施した.

球の位置は, 球の輪郭を画像処理して計測するため, 正確な位置計測を行うには, 球の輪郭が明確に判別出来 る様に可視化する必要がある. 球の表面に直接照明を当 てた場合, 球と照明の位置関係により形状が変化してし まう. そこで, 球の表面を黒く塗り, 照明を床面に当て ることで, 床からの反射光を球が遮る様に可視化した.

Fig. 2 は, 本研究で得られた画像の一例である. この図 に見られる様に，床面に照明を当てることによって，球 の輪郭が明確に捉えられることが分かる.

本研究では, 二球が角度を付けて衝突した場合の二球 の運動の詳細を調べることを目的としており, 常に一定 の角度で二球を衝突させる必要がある. そこで本研究で は，Fig. 2 に見られる様な設定で測定を行った. まず, 手球（図中央の 8 番）と的球（図右側の黒色の球）を直 線（理論的な的球の進行方向）上にお互いが接する様に 配置する. 次に, ダミーの球（図左上の 7 番）を手球に

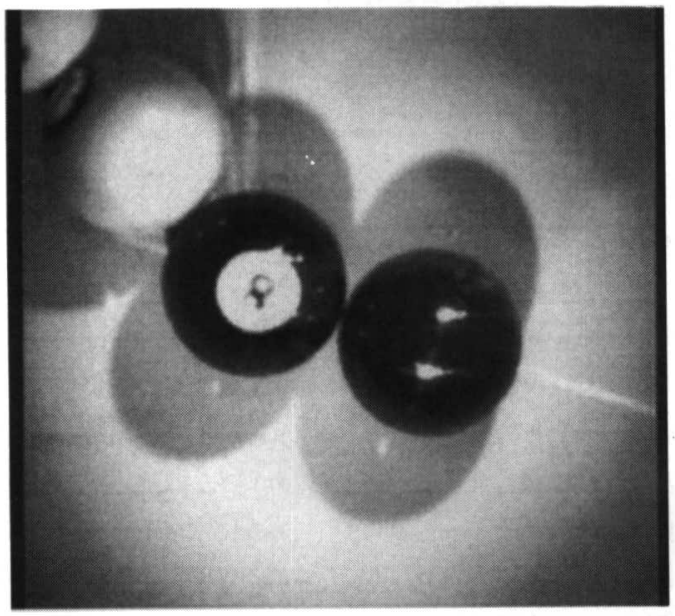

Fig. 2 Experimental setup for "throw"

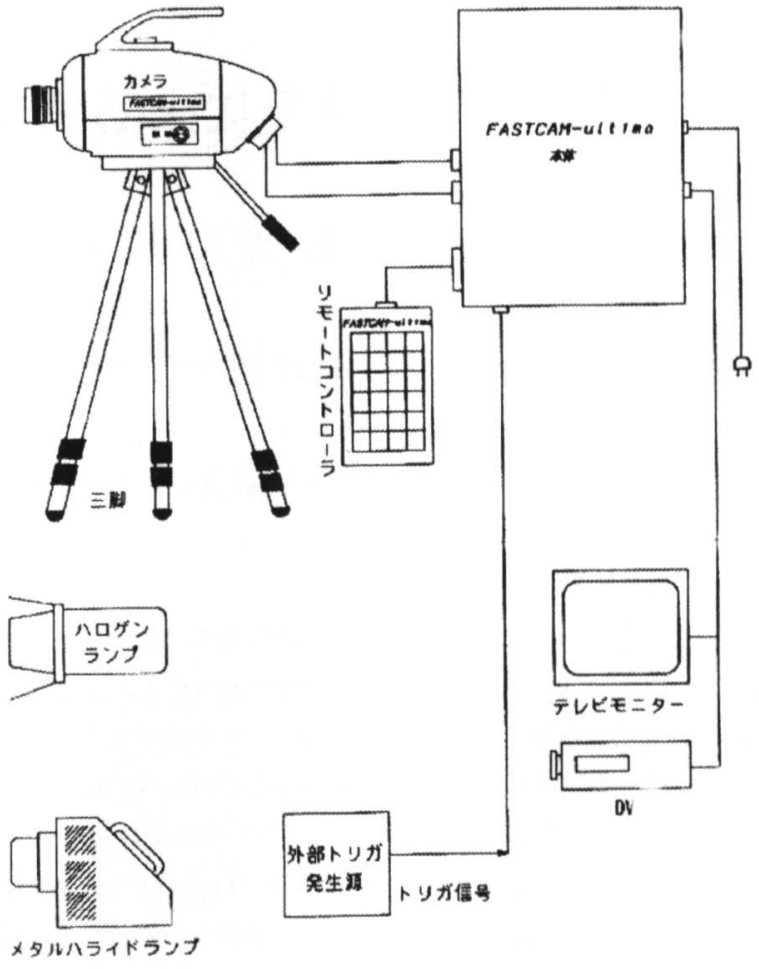

Fig. 1 High-speed camera system

接しつつ, ダミーの球と手球を結ぶ直線が先ほどの直線 と指定の角度をなす様に配置する．更に，もう一つダミ 一の球（図左上端の球）を手球から一直線に並ぶ様に配 置する.この配置を用いれば，後は二つ目のダミーの球 に適当な速度にて別の球を当ててやれば, 手球はダミー の球に押されて, 指定の角度で的球を押すこととなる.

Fig. 3 は, 衝突における二球の軌跡を模式的に示した 図であるが, 回転や摩摖などを伴わない質点同士の衝突 においては, 的球の進行方向である $u^{\prime}$ は, 手球の衝突 方向 $\mathrm{v}$ によらず, 衝突面である $\eta$ 軸に垂直な $\xi$ 軸方向 となるはずである. また, 手球の衝突後の進行方向であ る $v^{\prime}$ も完全弾性衝突においては $-\eta$ 軸方向に一致する はずである. しかし, 実際には種々の影響によって, u’ が やや $-\eta$ 軸方向にずれる「スロー」という現象が起こる.

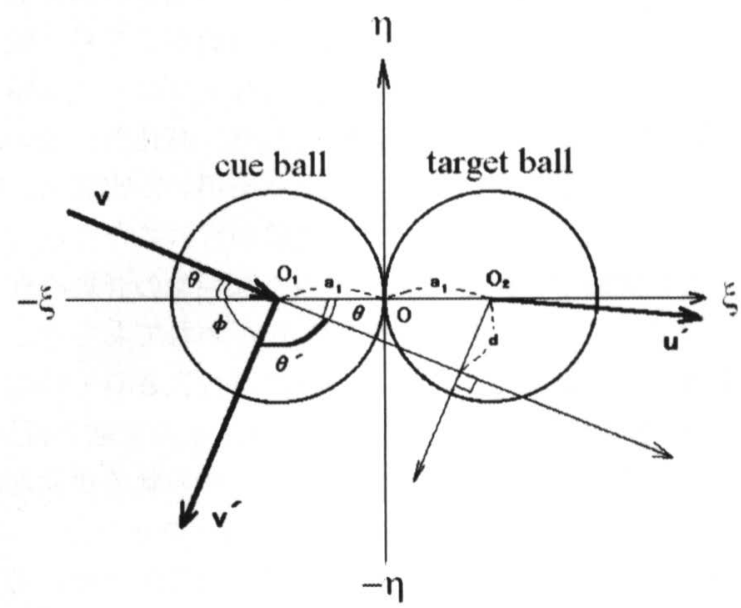

Fig. 3 Definition of angles about collision 


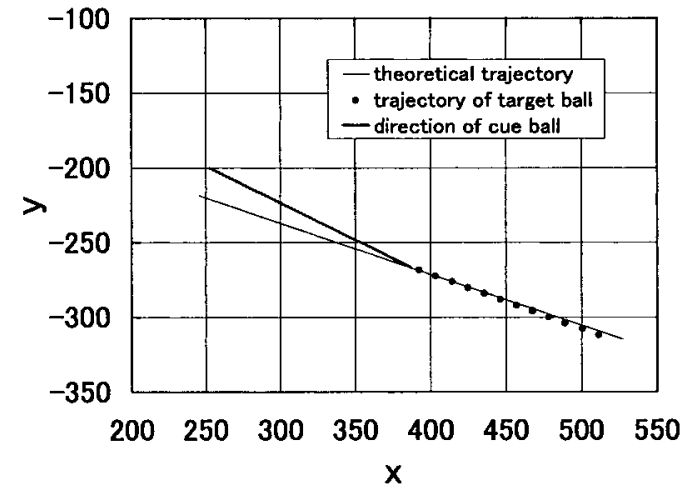

Fig. 4 Trajectories of balls (15 degree)

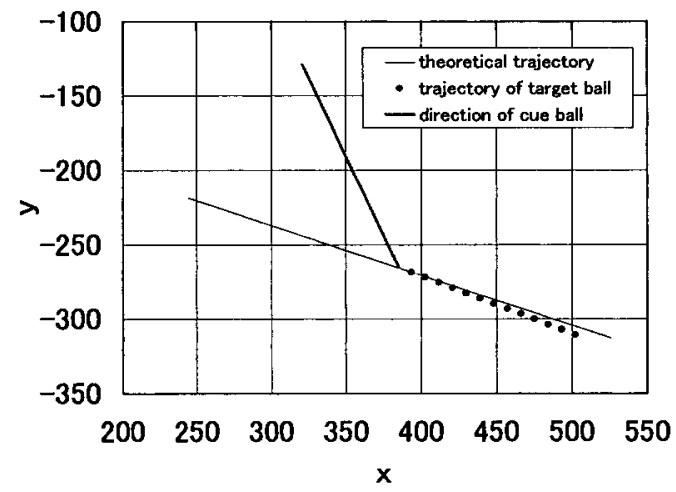

Fig. 6 Trajectories of balls ( 45 degree)

\section{4. 解析方法}

最初に，撮像倍率を決定するために金尺の画像を撮影 し, 一画素当たりの長さを求めた. 本測定では, 繸方向, 横方向とも $0.3 \mathrm{~mm}$ であった. 次に, 各時刻の画像から 球の輪郭を抽出する．まず， 8 近傍で輝度の平滑化を行 い,ノイズの影響を除去した。次に，8 方向のマスクを 施してエッジを抽出し, 二值化して輪郭線の画像を得た. 一般に, 画像から円や直線などの特徵を抽出する際には, 高速な処理が可能な Hough 変換を用いることが多いが, 位置計測の精度はあまり高くない.そこで本研究では, 得られた輪郭線画像に対し，円の方程式を最小二乗法に よって当てはめることで,精度の高い計測を可能とした. その結果, 0.1 画素以下の精度で円の中心座標を求める ことが可能となり，本研究における球の軌跡の計測誤差 は $0.03 \mathrm{~mm}$ 以下であると考えられる.

\section{5. 実験結果}

\section{1 球と球の角度を付けた街突}

Fig. 4 8 は, 手球と的球が種々の角度で衝突した場合 の理論的な二球の進行方向, 及び的球の軌跡の実測結果 を表した図である. 図中の青線は二つのダミーの球及び 手球の中心を結んだ線で, 衝突直前の手球に加えられた 力の向きを表している. つまり，この線が通常の二球の 衝突における手球の進行方向となる. また, 四中の赤線 は衝突前の手球と的球の中心を結んだ線を示しており，

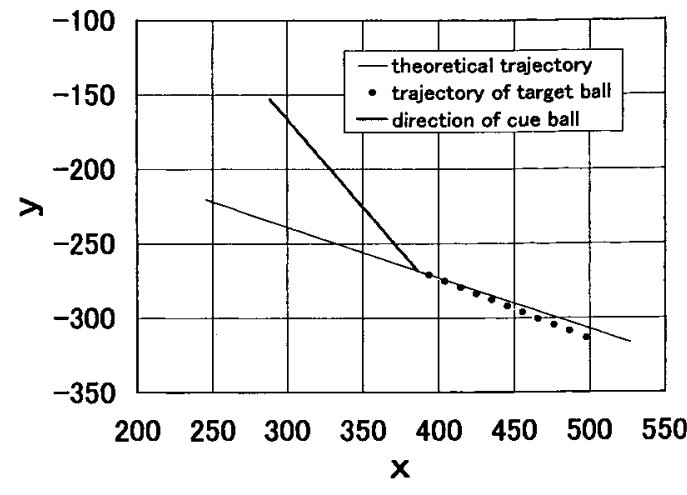

Fig. 5 Trajectories of balls (30 degree)

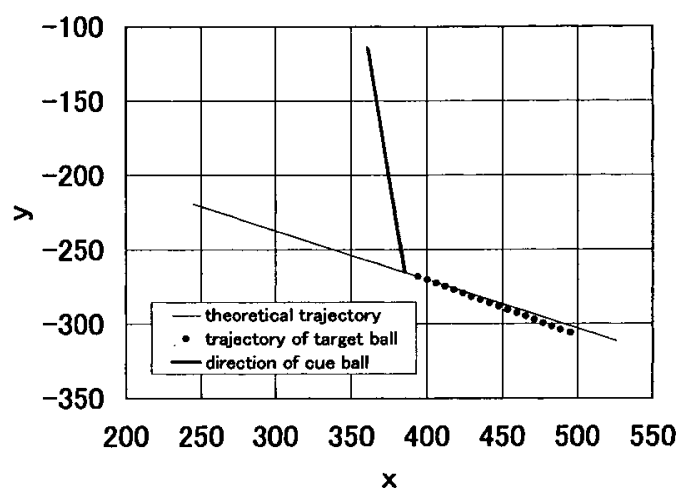

Fig. 7 Trajectories of balls ( 60 degree)

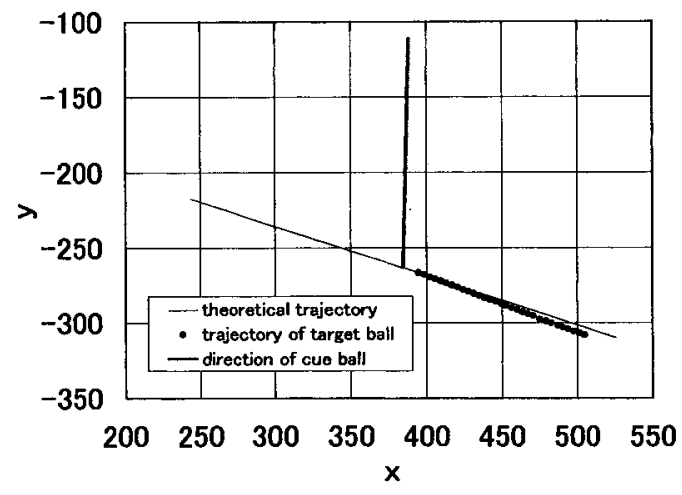

Fig. 8 Trajectories of balls (75 degree)

理論的な的球の進行方向を表す. 更に, 図中の黒点が画 像処理によって得られた的球の軌跡を表している.ここ で, Fig. 4 8 は各々順に手球之的球の成す角度が $15^{\circ}$, $30^{\circ}, 45^{\circ}, 60^{\circ}, 75^{\circ}$ の場合の結果を示している.

図に見られる様に，全ての衝突角において，的球の進 行方向が理論的な進行方向よりやや手球の進行方向側に ずれる「スロー」と呼ばれる現象が確認された．スロー が発生する原因は色々考えられるが，筆者らは衝突時の 摩摖の影響が大きいと推察する.つまり, 衝突時の的球 は手球から Fig. 3 の 軸方向に反発力を受けるだけで なく，わずかならがーク軸方向への摩擦力を受けている のである.この事は, 衝突面に水やチョークなどを人為 的に㙰布した状態で同様の実験を行った結果，ほとんど スローが見られなかった事実によっても確認される. 


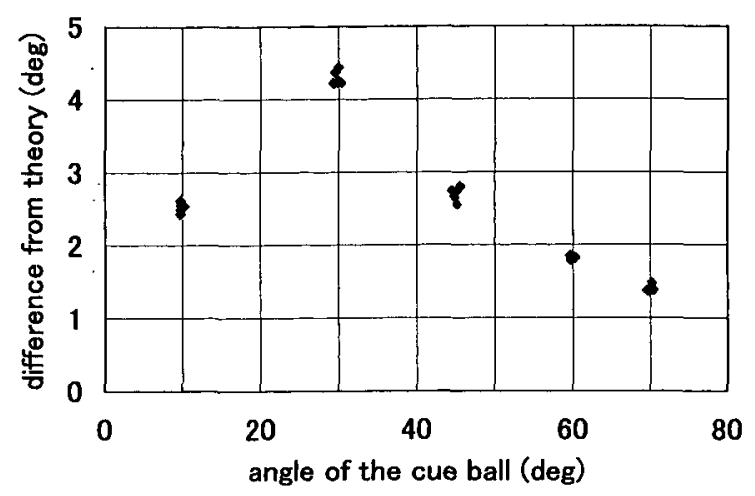

Fig. 9 Throw at various cue ball angles

\section{2 スローに及活す各種条件の影響}

以上により, 衝突時の手球之的球の角度によらず, 常 にスローが発生することが確認された. そこで, 本研究 では衝突時の手球と的球の角度によって, スローがぞう 变化するかを調べた. Fig. 9 は, 衝突時の手球之的球の 角度を種々変化させた場合のスローの角度の変化を示し た図である. 各々の角度における複数のデー夕点は, 手 球の速度の違いを表している.

この図から,スローの大きさは衝突時の手球之的球の 角度によって明らかに変化していることが分かる.また, その大きさは $30^{\circ}$ 付近で最大となり, 約 $4.3^{\circ}$ のずれと なった. 本研究においては, 特に的球の軌跡に着目して 解析を行ったため, 衝突後の手球の軌跡に関しては十分 な情報が得られていない．しかし，厚み $1 / 2$ の場合（衝 突前の手球と的球の角度が $30^{\circ}$ の場合に相当) の分離角 が 85.05ㄷなるという筆者らの既報 4)における測定結 果と合わせて考えると, 衝突後の手球の軌跡はほぼー 一 軸方向であると考えられる，つまり，スローと呼ばれる 現象は, 衝突後の手球と的球の分離角が $90^{\circ}$ よりわずか に小さくなる現象ではなく，的球の進行方向が衝突後の 手球方向にわずかにずれる現象であると考えられる.

このことは, スローの原因が衝突時の手球之的球の摩 擦によるとする前述の考察と符合する. 衝突時に的球が 一 $\boldsymbol{\eta}$ 軸方向の摩擦力を受けるとすると, 手球はその反作 用で ク軸方向の力を受ける.この力は, 衝突後の手球の 准行方向逆向きであり,手球の方向には影響を与えない.

尚、スローが $30^{\circ}$ の時に最大となる理由としては, 接 線力と反発力の兼ね合いが考えられるが，現時点ではそ の詳細は明らかではない。

次に, 衝突時の手球の速度がスローに与える影響を考 察する. Fig. 9 ではその影響があまり明確ではないので, Fig. 10 に衝突直前の手球の速度とスローの関保を示す.

図より, 衝突時の手球と的球の角度が $30^{\circ}, 45^{\circ}$, $60^{\circ}$ の場合に, 手球が遅くなるに連れてスローが大きく なる傾向が見受けられる．この傾向は習熟したプレーヤ 一が経験的に感じる現象と一致する.

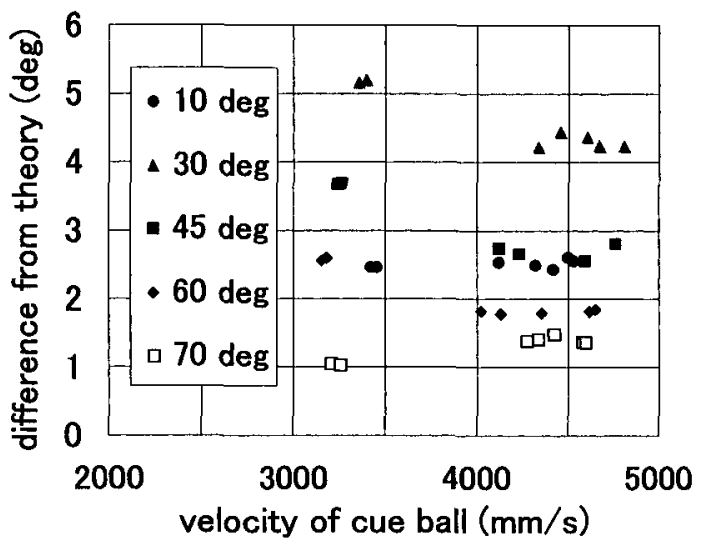

Fig. 10 Throw with various cue ball velocity

一方，衝突時の手球と的球の角度が $15^{\circ}$ 及び $75^{\circ}$ の 場合には, 逆に手球の速度が遅くなるに従って, スロー が若干小さくなる傾向が見受けられる.この傾向は，必 ずしも人間の感覚と一致する結果ではないが，この様に 角度が特に小さい，もしくは特に大きい場合は，人間の 視覚による角度の判断の信頼性にも疑問が持たれるため, この点については今後の検討課題とする.

\section{6. 結 論}

撞球において二球が角度を付けて衝突した場合の二球 の衝突挙動の詳細を明らかにするために, 高速度カメラ を用いた可視化を行い，画像処理により球の衝突挙動を 定量的に明らかにし，以下の結論を得た.

1）手球と的球の角度によらず, 衝突後の的球の進行方 向がわずかに衝突後の手球の進行方向にずれる「スロ 一」と呼ばれる現象が常に起こることが確認された.

2）スローの大きさは, 衝突時の手球之的球の角度が $30^{\circ}$ の時に, 最大の約 $4.3^{\circ}$ となり, その発生原因は 二球の摩擦であると推察した。

3）衝突時の手球の速度を変化させた所, 衝突時の手球 と的球の角度が $30^{\circ}, 45^{\circ}, 60^{\circ}$ の場合, 手球が遅 くなるに連れてスローが大きくなる傾向が見られた． 本研究においては, 宇都宮大学 SVBL ならびに地域共同 研究センターの設備を使用した. また実験に際して, 浦 井 勇技官の協力を得た. 記して謝意を表する.

\section{参考文献}

1) Shamos, M., and Jewett, B.: The Jacksonville Project, Clawson Cues (1998)

2) 須藤路久: Search for Scientific Truth of Billiards 1, 球's, Vol. 29, BAB ジャパン (2002.1) pp. 12-27.

3) 須藤路久 : Capture the Decisive Moment in Billiards 2, 球's, Vol. 34, BAB ジャパン (2002.6) pp. 8-23.

4）須藤路久，二宮 尚，秋山光庸，柳岡直行：「高速度力メラ を用いた準剛体球の衝突挙動解析」，可視化情報，V01. 22 Suppl., No. 1 (2002.7) pp. 153-156. 